Arq. Bras. Med. Vet. Zootec., v.56, n.2, p.157-167, 2004

\title{
Placental maturation and expulsion in Holstein and Nelore cows
}

[Maturação e expulsão placentária em vacas das raças Holandesa e Nelore]

\author{
V.M.V. Martins ${ }^{1}$, A.P. Marques Junior ${ }^{2}{ }^{*}$, A.C. Vasconcelos $^{3}$, E. Martins ${ }^{4}$, R.L. Santos ${ }^{2}$, F.P.C. Lima $^{5}$ \\ ${ }^{1}$ Departamento de Clínica e Patologia - CAV - UDESC \\ ${ }^{2}$ Escola de Veterinária da UFMG \\ Caixa Postal 567 \\ 30123-970 - Belo Horizonte, MG \\ ${ }^{3}$ Departamento de Patologia - ICB-UFMG \\ ${ }^{4}$ EPAGRI - Lages, SC \\ ${ }^{5}$ Estudante de Mestrado - EV-UFMG
}

\begin{abstract}
Morphological changes in the placenta at periparturition and the involvement of apoptosis controlling cell populations in the placentome were evaluated in Holstein and Nelore cows. Twenty-two Holstein cows at the end of gestation with normal non-induced parturition (group I) and 10 Holstein cows with induced parturition (group II) were used in this study. In addition, groups III and IV were constituted by 10 Nelore cows at the end of gestation with normal non-induced parturition and 21 Nelore cows with induced parturition, respectivelly. Binucleate trophoblastic cells, epithelial caruncular cells and apoptotic bodies were quantified by light microscopy. Apoptosis was further evaluated by transmission electron microscopy, ELISA and DNA electrophoresis in agarose gel. The number of caruncular epithelial cells did not vary between breeds with normal or induced parturition. The number of binucleate cells was significantly different between Holstein and Nelore cows with normal non-induced parturition (groups I vs. III), but their numbers were not significantly different between breeds when parturition was induced. In cows with normal non-induced parturition, the intensity of apoptosis, as assessed by morphometric analysis and ELISA, was significantly higher in group I when compared to group III. However, no difference in the intensity of apoptosis was found between groups II and IV. Characteristic apoptotic ladder pattern of DNA fragmentation was detected by agarose gel electrophoresis. Ultra-structural features of apoptosis in maternal and fetal epithelium as well as capillary vascular endothelium were identified by transmission electron microscopy. In conclusion, in Nelore placental maturation occurs precociously when compared to Holstein. In both breeds, apoptosis is an active physiological event that seems to be required for maturation and normal post-partum release of the placenta.
\end{abstract}

Keywords: bovine, placentome, binucleate cell, epithelial cell, apoptosis

\section{RESUMO}

Foram avaliadas as diferenças morfológicas e a participação da apoptose na população de células do placentoma de vacas das raças Holandesa e Nelore no periodo periparto. Foram utilizadas 22 vacas da raça Holandesa com parto a termo (tratamento I) e 10 com parto induzido (tratamento II). Nos tratamentos III e IV foram utilizadas 10 vacas Nelore com parto a termo e 21 com parto induzido, respectivamente. As células binucleadas trofoblásticas e epiteliais carunculares e os corpos apoptóticos foram quantificadas por microscopia óptica. A apoptose também foi avaliada por microscopia eletrônica de transmissão, ELISA e determinação da fragmentação do DNA por eletroforese em gel de agarose. $O$ número de células epitelilais carunculares não variou entre as raças com parto normal ou induzido. $O$

Suporte financeiro: FAPEMIG, Proc. 518/96

Recebido para publicação em 2 de dezembro de 2002

Recebido para publicação, após modificações, em 29 de dezembro de 2003

*Corresponding author

E-mail: ampinho@ufmg.br 
número de células binucleadas diferiu entre raças com parto a termo (tratamentos I e III); contudo seu número não variou quando o parto foi induzido. Em vacas com parto a termo a intensidade da apoptose foi significativamente maior no tratamento I do que no III, pela avaliação morfométrica e por ELISA. Entretanto, não foi encontrada diferença entre os tratamentos II e IV. A característica da fragmentação de DNA para a apoptose em eletroforese foi identificada pela presença de bandas com 200 pares de bases ou múltiplos. As caracteristicas da apoptose no epitélio materno e fetal e no endotélio vascular foram identificadas por microscopia eletrônica de transmissão. Os resultados permitem concluir que em vacas Nelore a maturação da placenta ocorre precocemente quando comparada à da raça Holandesa e que em ambas as raças a apoptose é um evento fisiológico ativo na maturação e eliminação da placenta.

Palavras-chave: bovino, placentoma, células binucleadas, apoptose

\section{INTRODUCTION}

Reproductive efficiency is a crucial factor for the success of the cattle industry, being directly related to the prompt recovery of the reproductive tract during the post-parturition period. Several changes in the cell population of the placentome take place throughout the gestation. Such changes are required for placental maturation and release of the fetal portion of the placenta after parturition. Placental maturation includes corium degeneration, maternal connective and epithelial tissues alterations (Wooding, 1983; Barreto Filho, 1992; Wango et al., 1992), and specially a significant decrease in caruncular epithelial cells and binucleate epithelial cells of the trophoblast (Gross et al., 1991; Williams et al., 1987; Santos, 1995).

Placental release and uterine involution are a finely controlled complex of physiological processes, therefore, these mechanisms can easily be disrupted (Steven, 1975; Eiler, 1997). It has been empirically observed that the occurrence of placental retention in zebu cows is lower when compared to European breeds. Furthermore, the length of gestation is shorter in zebu cattle as compared to European breeds (Barreto Filho, Marques Júnior, 1993).

Although studies comparing the physiology of parturition of zebu and European cattle are scarce in the literature, zebu cows have higher levels of relaxin at the end of gestation when compared to crossbred cattle. This finding may partially explain the low incidence of distocia in zebu cows (Randel, 1985). In addition, studies performed in periparturient Holstein cows demonstrated that when a significant decrease in the number of trophoblast binucleate cells fails to occur, fetal membranes become retained after parturition (Gross, Williams, 1988; Wagner, 1989). A decrease in the number as well as morphological changes in the caruncular epithelial cells are also required for a normal release of the fetal portion of the placenta after parturition in European breeds (Marques Júnior, 1988; Santos, 1995). In contrast, the dynamics of cell populations in the placentome of zebu cows, which may be related to normal parturition and placental expulsion are unknown.

Apoptosis has been described in blood vessels (Fesus et al., 1991) and as a regulatory mechanism for growth and involution of several hormone dependent tissues, including uterine epithelium, ovaries, mammary gland, prostate and testis (Kerr, 1992; Guenette et al., 1994; Atwood et al., 1995; Tilly, 1996). Characteristic DNA fragmentation associated with apoptosis was initially detected by agarose gel electrophoresis by the presence of a ladder pattern with bands multiple of approximately 200 base pairs (Wyllie, 1980; Vasconcelos, 1995; Sugerman et al., 1995). Therefore, previous studies reporting the occurrence of apoptosis in tissues of the reproductive system and the requirement for a decline in the number of trophoblastic binucleate and caruncular epithelial cells in cows with normal release of the placenta, suggests that programmed cell death might be involved in the placental release process.

It was empirically observed that the time from fetal expulsion to placental release is shorter in Nelore cows than in Holstein cows, and that the hystologic reorganization in the placentome seems to be precocious in zebu compared to Holstein cows, reinforcing the need to evaluate possible morphological differences between the placentomes of these two breeds. Thus, the present paper aimed to evaluate morphological differences between placentomes of Holstein and 
Nelore cows at periparturition and the occurrence of apoptosis during the placental maturation and release processes.

\section{MATERIAL AND METHODS}

Samples of placentomes were collected from 32 pluriparous Holstein cows, divided into group I, composed of 22 cows that had a normal postpartum delivered of the placenta, and group II, composed of 10 cows, which underwent induced parturition by intramuscular application of $25 \mathrm{mg}$ of dexametasone five days before the predicted date of delivery. In a beef ranch, placentomes were collected from 31 pluriparous Nelore cows, which were divided into group III, composed of 10 cows that had normal delivery and release of the placenta within eight hours after fetal expulsion, and group IV, composed of 21 cows, which underwent induced parturition by intramuscular injection of $25 \mathrm{mg}$ of dexametasone five days prior to the predicted date of delivery. The sample size of cows per treatment was calculated considering a $\mathrm{CV}=25 \%$, admitting a confidence interval of $20 \%$ of the average. Time of delivery and placenta elimination were followed up until 24 hours after parturition. Placentas were considered retained when not released up to eight hours after fetal expulsion.

Placentome sampling was performed immediately after fetal expulsion. One placentome was collected from the distal region of the uterus according to technique previously described by Marques Júnior (1988). From each collected placentome, three fragments were removed for caruncular epithelial cells, trophoblast binucleate cells and apoptotic bodies quantification by light microscopy. Five fragments were collected to evaluate apoptosis through transmission electron microscopy and for determination of apoptosis by ELISA. A fragment was collected from randomly selected placentomes for agarose gel eletrophoresis.

Samples for light microscopy were fixed by immersion in buffered paraformaldehyde (paraformaldehyde at $4 \%$ in buffer phosphate 0.1 $\mathrm{M}, \mathrm{pH} 7.3$ ) for 24 hours. The tissue samples were processed for embedding in glycol metacrilate plastic resin. Histological sections ( $3 \mu \mathrm{m}$ thick) were stained with hematoxylin and eosin. Three sections from each placentome, with at least by $50 \mu \mathrm{m}$ between each other, were examined.
Samples for transmission electron microscopy were fixed by immersion in a modified KARNOVSKY solution (glutaric aldehyde at $2.5 \%$, paraformaldehyde $2.0 \%$ in buffer sodium cacodilate $1 \% \mathrm{M}$ and $\mathrm{pH} 7.3$ with $0.07 \%$ calcium chloride) at $4^{\circ} \mathrm{C}$ for four hours. The specimens for ELISA test and eletrophoresis were kept frozen in liquid nitrogen until further processing. A commercial ELISA kit was used for assessment of apoptosis.

In order to quantify the caruncular epithelial cells, microscopic images were captured with a $40 \times$ planapochromatic objective using the Kontron Electronic GMBH image analyzer with the KS300 program. A $100 \mu \mathrm{m}$ line was superimposed paralleling the caruncular epithelium to define the length of epithelium in which the cells were counted. Three slides were mounted from each one of the three placentome sections. Four randomly selected fields were counted from each slide, totaling 36 microscopic fields per placentome, from which the average number of cells in an extension of $100 \mu \mathrm{m}$ of caruncular epithelium was determined.

Microscopic images captured with a 40X planapochromatic objective were transferred to an image analyzer with the KS300 program. Quantification of placentome binucleate cells was accomplished in $53.322,7 \mu \mathrm{m}^{2}$ microscopic fields. From a total of 36 fields, the average number of binucleate cells per microscopic field was determined. Apoptotic cells were characterized by intensely eosinophilic cytoplasm and condensation of the chromatin forming densely basophilic bodies of variable shapes and sizes.

The apoptotic rate, as assessed by ELISA, was based on a quantitative immunoenzimatic sandwich in which a mouse monoclonal antibodies is used directly against DNA and histones, allowing detection of specific mono and oligonucleossomes in the cytoplasmatic fraction of lysed cells.

Placentome DNA samples were dissolved in Tris-EDTA buffer and run in an agarose gel stained with etidium bromide for detection of DNA fragmentation, which was quantified by spectrophotometry.

Ultra-thin sections of placentomes were mounted onto copper screens and evaluated using an 
electronic microscope, with magnifications ranging from 1.260 to $15.000 \times$. The following ultrastructural changes were considered characteristic features of apoptosis: retraction of the cell and its detachment from adjacent tissue, condensation of chromatin and nuclear fragmentation, formation of digit shaped projections of the cytoplasmatic membrane and apoptotic bodies, which were characterized by the presence of cytoplasm and organelle agglomeration with or without nuclear fragments.

An entirely random experimental design was used (Cochran, Cox, 1957). The average numbers of epithelial and binucleate cells, and apoptotic bodies evaluated by morphometry as well as the apoptotic rates determined by ELISA were submitted to analysis of variance and the averages were compared by the Student $t$ test. The frequencies of placental retention in different groups were compared by the Fisher's exact test (Snedecor, Cochran, 1994).

\section{RESULTS AND DISCUSSION}

Holstein cows from group I had in average $4 \mathrm{~h}$ and $23 \mathrm{~min}$ (ranging from $1 \mathrm{~h}$ and $45 \mathrm{~min}$ to $6 \mathrm{~h}$ and $55 \mathrm{~min}$ ) from fetal expulsion until complete release of the placenta. In group II, three cows released the placenta with an average of $3 \mathrm{~h}$ and $43 \mathrm{~min}$ after fetal expulsion. The remaining seven cows from group II did not released the placenta within $8 \mathrm{~h}$ after fetal expulsion, and six of them retained the placenta for more than $24 \mathrm{~h}$. The Nelore cows from groups III and IV released their placentas within $2 \mathrm{~h}$ after fetal expulsion, with exception of one of the 21 cows $(4.8 \%)$ from group IV, which retained the placenta for more than $8 \mathrm{~h}$.

Barreto Filho (1992), while studying placentome morphology of zebu cows during pregnancy and in immediate post-partum, found it difficult to obtain intact samples for morphologic evaluation, since at a few minutes after fetal expulsion there was already separation between fetal and maternal tissues. In the present study, at 30 minutes after fetal expulsion there was already separation between fetal and maternal tissues in the placentome of zebu cows, which prevented an adequate sampling. Randel (1985) observed that Brahman cows had higher levels of relaxin than Bos taurus taurus cows at 12 days prior to delivery. According to this author, this endocrine profile could partly explain the low incidence of dystocia in zebu cows. Higher levels of relaxin might also contribute to the quick release of the placenta in zebu animals. In Holstein cows, the time required for placental release ( $4 \mathrm{~h}$ and $23 \mathrm{~min}$ ) was similar to that previously reported by Santos (1995). These findings indicate that the maturation of the placenta in zebu is precocious when compared to Holstein cows, which is in agreement with a previous report indicating that the hystologic reorganization of the caruncula occurs earlier in zebu (Barreto Filho, 1992).

Considering the cows that underwent induced parturition (groups II and IV), the incidence of placental retention in Nelore cows was significantly lower than in Holstein cows (4.76 vs. $70.0 \%$, respectively; $\mathrm{P}=0.0003)$. The $70 \%$ rate of placental retention in Holstein cows was similar to previous reports in which delivery was induced by administration of glycocorticoides (Wagner, 1989).

The average number of maternal epithelial cells are presented in Table 1. The number of maternal epithelial cells were not significantly different between groups with normal non-induced parturition (groups I vs. III; $\mathrm{P}<010$ ) as well as in groups with induced parturition (groups II and IV; $\mathrm{P}<0.10$ ). In contrast, comparing the number of these cells in each breed, it was observed that in Holstein cows with normal non-induced delivery, the number of cells was significantly lower than in placentomes of cows that underwent induced delivery $(\mathrm{P}<0.01)$. It is noteworthy that the incidence of placental retention was significantly higher in group II. No significant difference was detected in the number of maternal cells in Nelore cows with or without induction of parturition (groups III vs IV; $\mathrm{P}>0.10)$.

Table 1. Number of maternal epithelial cells in bovine placentomes according to the groups in Holstein and Nelore cows

\begin{tabular}{lc}
\hline Group & Mean \pm standard deviation \\
\hline I $(\mathrm{n}=22)$ & $3.59 \pm 0.59 \mathrm{a}$ \\
II $(\mathrm{n}=10)$ & $4.73 \pm 1.56 \mathrm{~b}$ \\
III $(\mathrm{n}=10)$ & $4.02 \pm 0.40 \mathrm{ab}$ \\
IV $(\mathrm{n}=21)$ & $4.36 \pm 0.59 \mathrm{~b}$ \\
\hline
\end{tabular}

Different letters in the same column indicate significant difference $(\mathrm{P}<0.05)$.

I -Holstein cows with normal non-induced delivery; II Holstein cows with induced delivery; III -Nelore cows with normal non-induced delivery; and IV -Nelore cows with deliver induced five days prior to the predicted date. 
These results reinforce the hypothesis that placental maturation occurs precociously in Nelore cows when compared to Holstein cows, since the low incidence of placental retention in Nelore cows that underwent induced parturition $(1 / 21)$ is associated with a lack of significant difference in the number of maternal epithelial cells between cows with or without induction of parturition. In sharp contrast, Holstein cows, which had a higher incidence of placental retention as a result of induction of parturition, also had a higher number of maternal epithelial cells in the placentome in those cows that underwent induction of parturition, suggesting an incomplete maturation of the placentome. Placental maturation is characterized by a decrease in the number of maternal epithelial cells (Wango et al., 1992; Santos, 1995), which seems to be required for a normal release of the fetal membranes. The number of maternal epithelial cells found in this work is similar to that reported by Marques Júnior (1988) and
Santos (1995) in Holstein animals and by Barreto Filho and Marques Júnior (1993) in zebu.

Caruncular epithelium in placentomes from Holstein cows with normal non-induced parturition was mostly flat, composed by cells with long nuclei and intensely vacuolated cytoplasm (Fig. 1A). However, in placentomes from cows with induced delivery, maternal epithelium in many microscopic fields was composed by cuboidal cells with rounded nucleus and a few cytoplasmic vacuoles (Fig. 1B). These microscopic features were previously described (Williams et al., 1987; Santos, 1995). In Nelore cows the caruncular epithelium was similar to that observed in placentomes from Holstein cows with normal non-induced parturition (Fig. 1A), regardless of induction of parturition, further supporting the hypothesis that placenta maturation in zebu is precocious when compared to Holstein cows.

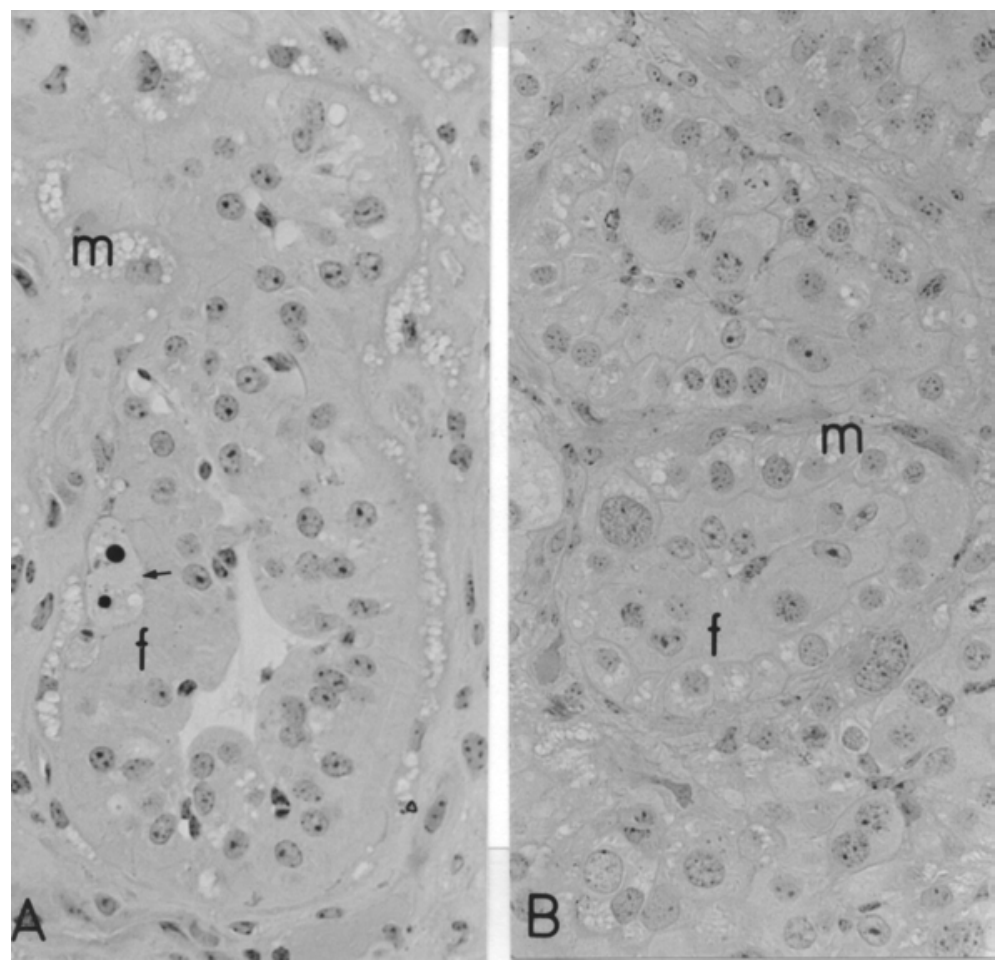

Figure 1. Placentome of holstein cow. A- normal non-induced delivery. Caruncular epithelium composed by flatten cells with vacuolated cytoplasm (m); fetal epithelium with main and binucleate cells (f); binucleate cell in apoptotis (arrow). B- induced delivery: maternal epithelium composed by cuboidal cells with round nuclei (m), and fetal epithelium (f). 400×. 
Ultrastructural detection of microvilli junctions between maternal and fetal epithelium indicated a higher degree of integrity in placentomes of Holstein cows with induced parturition (Fig. 2). This finding suggests that increase in the proteolitic activity in the extracellular matrix of the maternal/fetal interface takes place at a very late stage of the gestation, right before parturition.

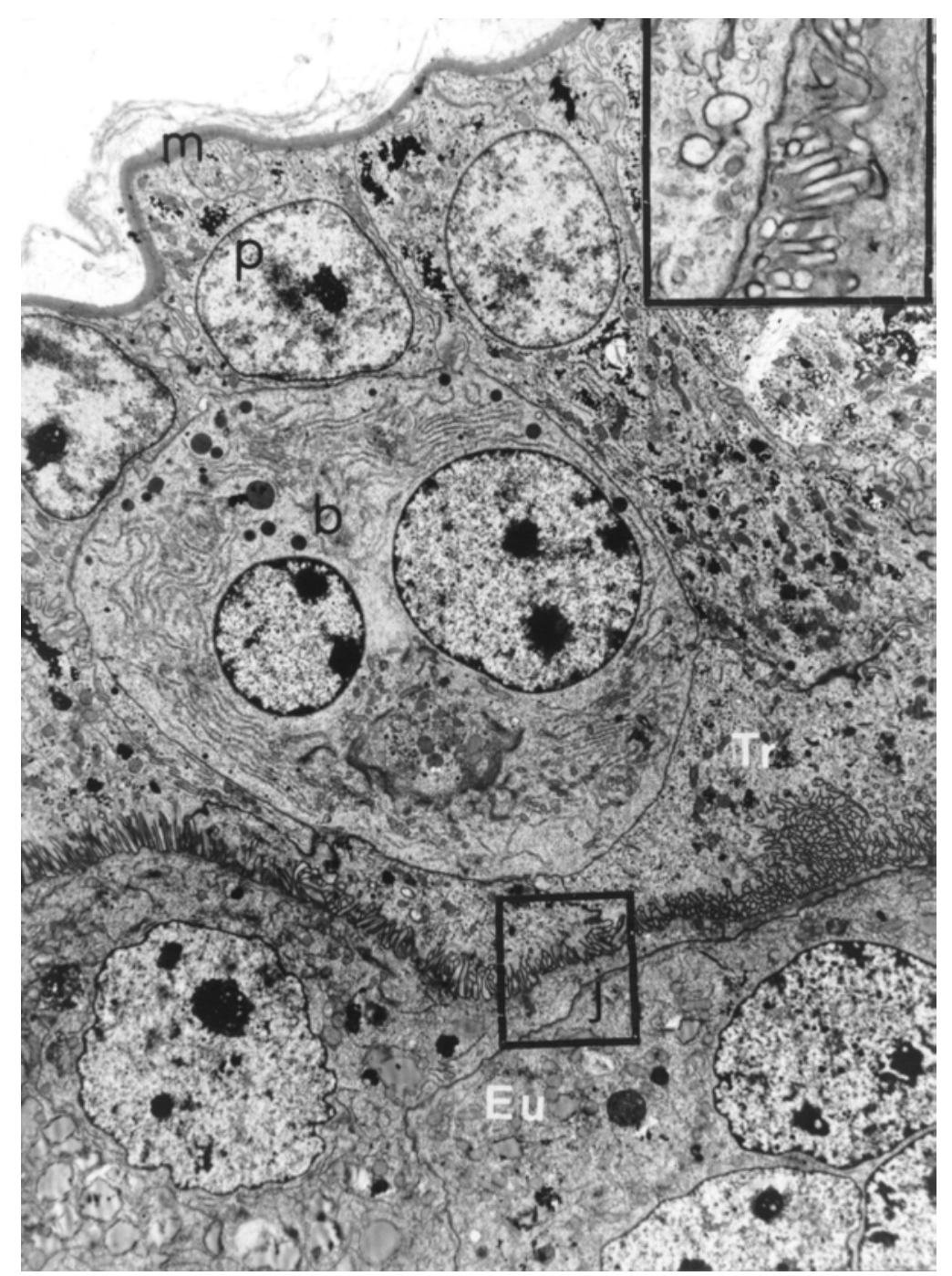

Figure 2. Electron photomicrographiy of a Holstein cow placentome with induced delivery. Caruncular epithelium (Eu) with multinucleate cell in the bottom right corner; trophoblastic epithelium (Tr) with binucleate cell (b), main cells (p) and basal membrane (m); maternal/fetal microvilus interdigitation (j) in the upper box. $2900 \times$.

The average number of binuclear cells per microscopic field are shown in Table 2. In cows that had a normal non-induced parturition, the average number of trophoblastic binucleate cells was significantly lower in Holstein than in
Nelore cows (groups I vs. III; $\mathrm{P}<0.05$ ). However, when parturition was induced (groups II and IV), no significant difference was detected between breeds in the number of binucleate cells $(\mathrm{P}>0.10)$. 
Table 2. Number of trophoblastic binucleate cells in bovine placentomes according to the groups in Holstein and Nelore cows

\begin{tabular}{lc}
\hline Group & Mean \pm standard deviation \\
\hline I $(n=22)$ & $3.69 \pm 1.38 \mathrm{a}$ \\
II $(\mathrm{n}=10)$ & $11.40 \pm 1.44 \mathrm{~b}$ \\
$\mathrm{III}(\mathrm{n}=10)$ & $4.92 \pm 1.24 \mathrm{c}$ \\
IV $(\mathrm{n}=21)$ & $11.03 \pm 1.50 \mathrm{~b}$ \\
\hline
\end{tabular}

Different letters in the same column indicate significant difference $(\mathrm{P}<0.05)$.

I -Holstein cows with normal non-induced delivery; II Holstein cows with induced delivery; III -Nelore cows with normal non-induced delivery; and IV -Nelore cows with deliver induced five days prior to the predicted date.

In normal non-induced parturitions, the larger number of binucleate cells in zebu cows may indicate an intrinsic characteristic of the breed. This would partly explain the faster fetal delivery and release of the placenta since these cells secrete PGF2 $\alpha$ (Gross, Williams, 1988), which plays an active role in parturition and placental expulsion. However, an increased number of trophoblastic binucleate cells has been demonstrated to be associated with placental retention (Williams et al., 1987; Santos, 1995). The number of binucleate cells found in Holstein cows with normal non-induced parturition was similar to that observed by Santos (1995). These results are similar to the previously reported by Gross et al. (1991), who demonstrated that in induced labor the number of cells was significantly higher than in term delivery. However, the same authors observed that in induced delivery the number of binucleate cells did not differ in relation to the amount found in cows with term delivery followed by placental retention. The results obtained suggest that the number of binucleate cells plays a minor role in the pathogenesis of placental retention since the incidence of retention in Nelore cows was significantly lower than in Holstein cows under the same protocol for induction of parturition.

Hystologically, trophoblast epithelium is composed by two distinct cell types, namely, main and binucleate cells, the last form trinuclear or multinucleate cells when they merge with caruncular epithelial cells (Fig. 3). This phenomenon prompted Wooding (1992) to describe the ruminant placenta as sinepitheliocorial.

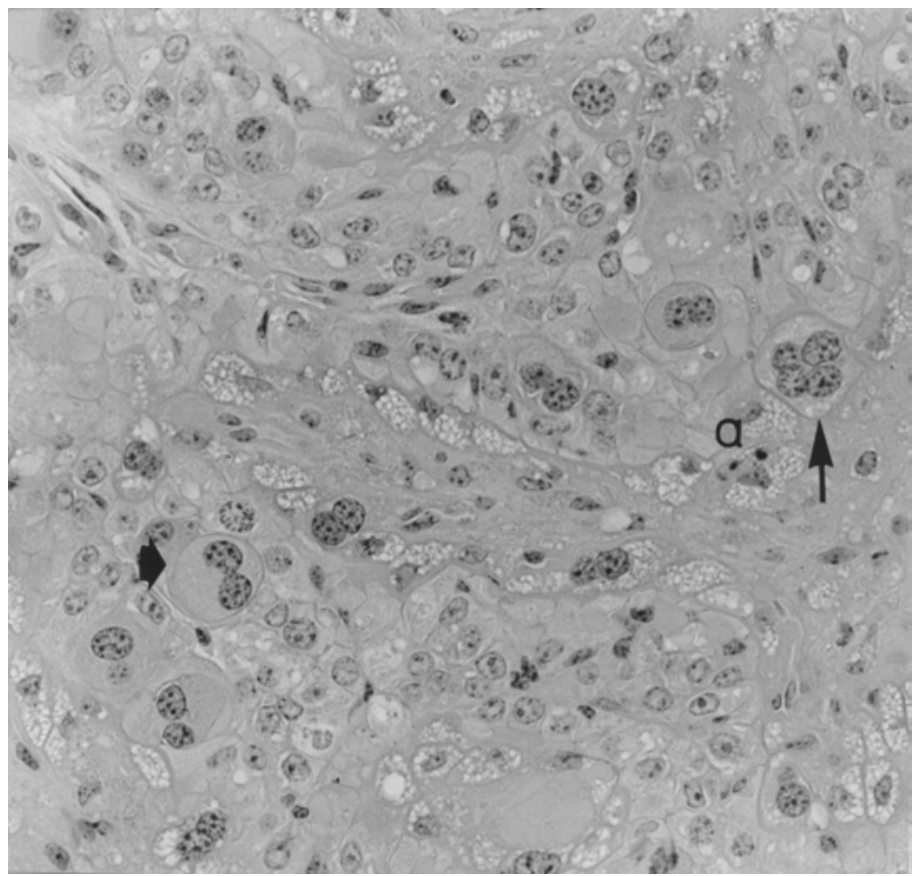

Figure 3. Synepitheliochorial placenta in zebu cow with normal non-induced delivery: migration of binucleate cells into the maternal epithelium (large arrow) forming a fetal-maternal hybrid with multinucleate cells (arrow); apoptotic body in the maternal epithelium (a). HE. 400×. 
The average number of apoptotic bodies as detected by light microscopy are shown in Table 3. Among the cows with non-induced parturition, the number of apoptotic bodies was significantly higher in Holstein cows than in Nelore cows (groups I vs. III; $\mathrm{P}<0.01$ ). In induced deliveries there was a tendency to a higher number of apoptotic bodies in Nelore cows when compared to Holstein cows (groups II vs. IV; $\mathrm{P}<0.07$ ), although the difference was not statistically significant.

Table 3. Number of apoptotic bodies in bovine placentomes according to the groups in Holstein and Nelore cows

\begin{tabular}{lc}
\hline Group & Mean \pm standard deviation \\
\hline I $(\mathrm{n}=22)$ & $13.49 \pm 0.93 \mathrm{a}$ \\
II $(\mathrm{n}=10)$ & $5.02 \pm 1.18 \mathrm{bc}$ \\
III $(\mathrm{n}=10)$ & $3.46 \pm 1.24 \mathrm{~b}$ \\
IV $(\mathrm{n}=21)$ & $6.82 \pm 3.90 \mathrm{c}$ \\
\hline
\end{tabular}

Different letters in the same column indicate significant difference $(\mathrm{P}<0.05)$.

I -Holstein cows with normal non-induced delivery; II Holstein cows with induced delivery; III -Nelore cows with normal non-induced delivery; and IV -Nelore cows with deliver induced five days prior to the predicted date.

The apoptotic rate in the placentome as determined by the ELISA test is shown in Table 4. The absorbance readings obtained in samples from Holstein cows with normal non-induced parturition (group I) was significantly higher
$(\mathrm{P}<0.05)$ than in samples from Nelore cows (group III) under the same conditions. However, in cows with induced delivery (groups II and IV) there was no significant difference between groups $(\mathrm{P}>0.10)$.

Table 4. Absorbance units (indicative of the apoptotic rate) in bovine placentomes according to the groups in Holstein and Nelore cows

\begin{tabular}{lc}
\hline Group & Mean \pm standard deviation \\
\hline I $(\mathrm{n}=22)$ & $443.64 \pm 170.85 \mathrm{a}$ \\
II $(\mathrm{n}=10)$ & $360.50 \pm 86.91 \mathrm{ab}$ \\
III $(\mathrm{n}=10)$ & $327.30 \pm 107.46 \mathrm{~b}$ \\
IV $(\mathrm{n}=21)$ & $405.90 \pm 158.68 \mathrm{ab}$
\end{tabular}

Different letters in the same column indicate significant difference $(\mathrm{P}<0.05)$.

I -Holstein cows with normal non-induced delivery; II Holstein cows with induced delivery; III - Nelore cows with normal non-induced delivery; and IV -Nelore cows with deliver induced five days prior to the predicted date.

DNA analysis demonstrated the characteristic ladder pattern of fragmentation indicative of apoptosis. Such ladder pattern is characterized by bands multiple of 200 base pairs (Fig. 4a), and has been previously demonstrated to be associated with apoptosis in other tissues (Wyllie, 1980; Vasconcelos, 1995; Sugerman et al., 1995). The characteristic ladder pattern was not observed in control cells, in which a homogeneous smear was observed near the well in the electrophoresis gel (Fig. 4b).
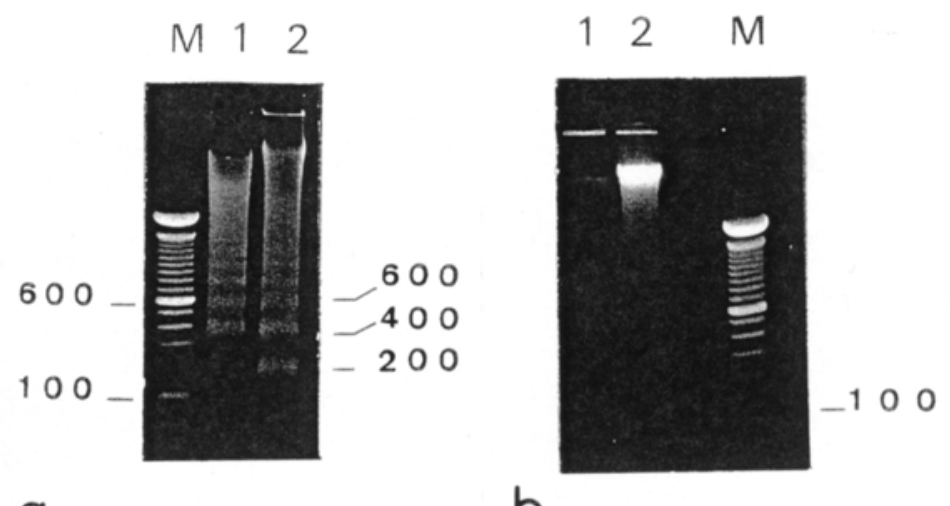

Figure 4. Agarose gel electrophoresis of DNA extracted from placentomes of Holstein cows. a - standard characteristic of apoptotic DNA fragmentation - molecular weight marker (M), and columns 1 and 2 loaded with DNA from placentomes with internucleosomal fragmentation indicative of apoptosis; $b$ columns 1 and 2 with DNA from control non-apoptotic cells without fragmentation, forming a band of intact DNA at the top. 
Cells in different stages of apoptosis were observed, which were characterized by nuclear heterochromatin condensation, formation of uniform dense masses aligned to the internal side of the nuclear membrane, nuclear membrane convolutions and fragmentation, cell wrinkling with digit shaped projections of the cytoplasmatic membrane and formation of apoptotic bodies. These ultra-structural changes are similar to the ones described in other tissues (Kerr, 1992; Vasconcelos, 1995). Apoptosis was detected in fetal and maternal epithelial tissues and also in blood capillary endothelium in both maternal and fetal portions of the placentome (Fig. 5). The occurrence of apoptosis in the capillary vessel endothelium probably contributes to the decrease in placentome blood flow and, therefore, it favors programmed cell death of epithelial cells, since hypoxia is an activating factor of apoptosis. Thus, apoptosis of the endothelium and epithelium seems to favor detachment of the fetal membranes after fetal expulsion.

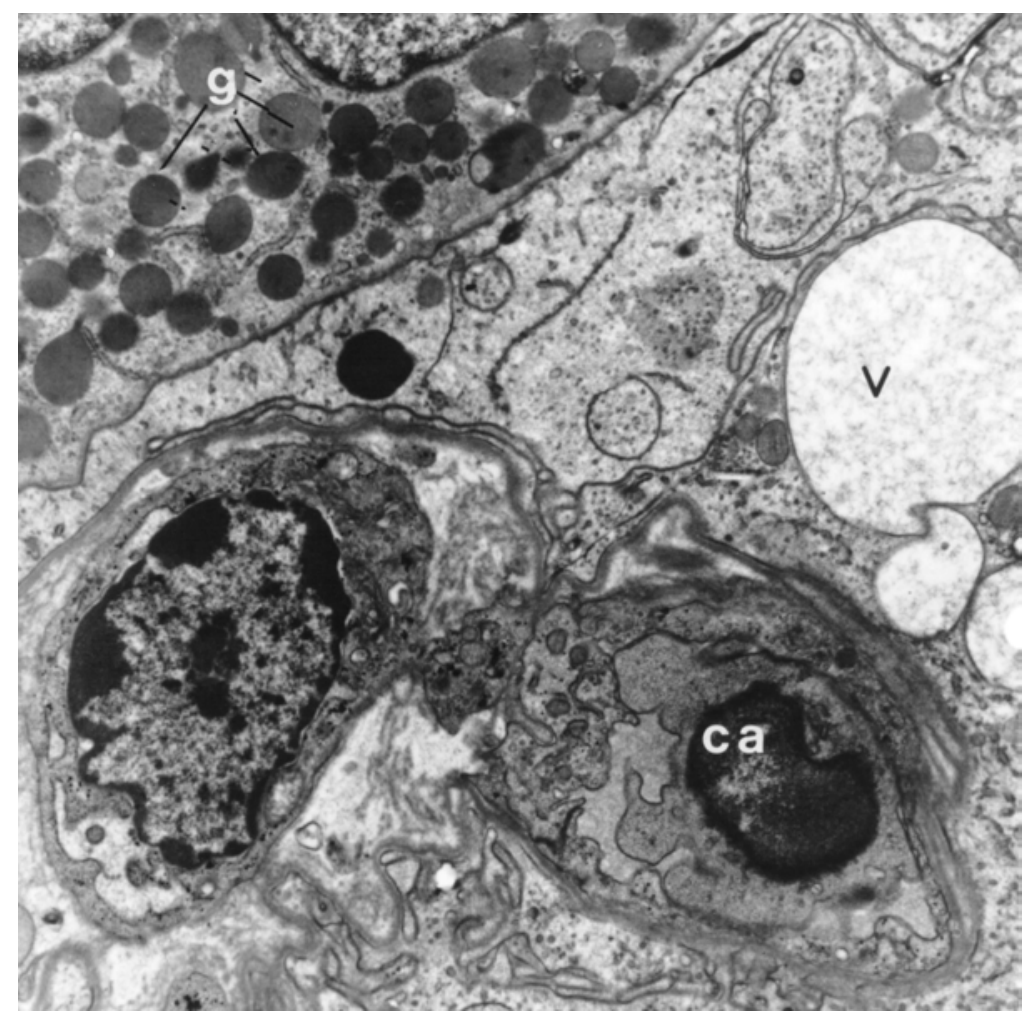

Figure 5. Electron photomicrography of a placentome from a Holstein cow with induced delivery. Endothelial cell in the trophoblast with morphological features of apoptosis (ca); segment of a binucleate cell with cytoplasmic secretory granutes (g); cytoplasmatic vacuole (v). 9.900×.

The significantly higher number of apoptotic bodies observed in Holstein cows with noninduced delivery (group I), when compared to zebu (group III), supports the notion that cell removal and placenta expulsion occurs earlier in Nelore than in Holstein cows. Apoptosis in the placentome of Holstein cows occurs with greater intensity at the moment of delivery.
Comparing the two methods employed for detection of programmed cell death, it was observed that the apoptotic rates determined by the ELISA test was similar to results obtained by counting apoptotic bodies under light microscopy. Nevertheless, differences between the two methods are probably due to the higher sensitivity of the ELISA test during the initial 
stages of the process, whereas the morphological changes are detected only at later stages.

When apoptotic rates were compared between Holstein cows with normal non-induced parturition and zebu cows with induced delivery, there was no significant differences, which supports the hypothesis that, in Holstein cows, cell elimination and completion of the placental maturation process takes place during delivery or just before the onset of delivery. On the other hand, in Nelore cows programmed cell death and complete maturation of the placenta seems to occur precociously. These differences might contribute to lower rates of dystocia and placental retention in zebu cows, which was also suggested by Barreto Filho (1992), who demonstrated that caruncular hystologic reorganization in zebu begins even before delivery.

\section{CONCLUSIONS}

Based on the conditions in which this study was conducted, it was concluded that: in Nelore cows placenta maturation occurs precociously when compared to Holstein cows; the time span from fetal expulsion and placental release is shorter in Nelore cows than in Holstein cows; in Nelore cows induction of delivery with dexametasone five days prior to the predicted date did not interfere with the amount of time required for placental expulsion; the number of apoptotic bodies is lower in Holstein cows with induced parturition.

\section{REFERENCES}

ATWOOD, C.S.; IKEDA, M.; VONDERHAAR, B.K. Involution of mouse mammary glands in whole organ culture: a model for studying programmed cell death. Biochem. Biophy. Res. Commun., v.207, p.860-887, 1995.

BARRETO FILHO, J.B. Aspectos morfofisiológicos da placentação do zebu (Bos taurus indicus). 1992. 106f. Dissertação (Mestrado) - Escola de Veterinária, Universidade Federal de Minas Gerais, Belo Horizonte.

BARRETO FILHO, J.B.; MARQUES JUNIOR, A.P., Aspectos histológicos da placenta de vacas zebu. Arq. Bras. Med. Vet. Zootec., v.45, p.385-
393, 1993.

COCHRAN, W.G.; COX, G.M. Experimental designs. 2.ed. New York: John Wiley \& Sons, 1957. 611p.

EILER, H. Retained placenta. In: YOUNGQUIST, R. (Ed.). Current therapeutics in large animals theriogenology. Philadelphia: W.B. Saunders, 1997. p.340-348.

FESUS, L.; DAVIES, P.J.A.; PIACENTINI, M. Apoptosis: molecular mechanisms in programmed cell death. Europ. J. Cell Biol., v.56, p.170-177, 1991.

GROSS, T.S.; WILLIAMS, W.F. Bovine placental prostaglandin synthesis: principal cell synthesis as modulated by the binucleate cell. Biol. Reprod., v.38, p.1027-1034, 1988.

GROSS, T.S.; WILLIAMS, W.F.; RUSSEKCOHEN, E. Cellular changes in the peripartum bovine fetal placenta related to placental separation. Placenta, v.12, p.27-35, 1991.

GUENETTE, R.S.; CORBEIL, H.B.; LEGER, J.G. et al. Induction of gene expression during involution of the lactating rat mammary gland. $J$. Mol. Endocrinol., v.12, p.47-60, 1994.

KERR, J.B. Spontaneous degeneration of germ cells in normal rat testis: assessment of cell types and frequency during the spermatogenic cycle. $J$. Reprod. Fertil., v.95, p.825-830, 1992.

MARQUES JÚNIOR, A.P. Leucocyte chemotaxis activity by cotiledons of dairy cows with normal delivery and retained placenta. 1988. 182f. Thesis (PhD) - University of Illinois, Urbana-Champaingn, IL.

RANDEL, R.D. Endocrine aspects of the zebu cow. CONGRESSO BRASILEIRO DE REPRODUÇÃO ANIMAL, 8., Belo Horizonte. Anais... CBRA, 1989. p.1-13, 1985.

SANTOS, R.L. Estudo morfológico da placenta de vacas leiteiras com liberação normal e com retenção., 1995. 102f. Dissertação (Mestrado) Escola de Veterinária, Universidade Federal de Minas Gerais, Belo Horizonte.

SNEDECOR, G.W.; COCHRAN, W.G. Statistical methods. 8.ed. Ames: Iowa State University, 1994. 503p.

STEVEN, D.H., Anatomy of the placental barrier. In: COMPARATIVE placentation. 
London: Academic, 1975. p.25-57.

SUGERMAN, P.B.; JOSEPH, B.K.; SAVAGE, N.W. Review article: The role of oncogenes, tumour suppressor genes and growth factors in oral squamous cell carcinoma: a case of apoptosis versus proliferation. Oral Dis., v.1 p.172-188, 1995.

TILLY, J.L. Apoptosis and ovarian function. Rev. Reprod., v.1, p.162-172, 1996.

VASCONCELOS, A.C. Apoptose ou morte celular programada e sua importância em patologia veterinária. In: ENCONTRO NACIONAL DE PATOLOGIA VETERINÁRIA, 7. 1985, Belo Horizonte. Anais... Escola de Veterinária da UFMG, 1995. p. 69-77,

WAGNER, W.C. Endocrine physiology of the parturient cow and placental retention. Rev. Bras. Reprod. Anim., v.13, suppl.1, p.61-74, 1989.

WANGO, E.O.; HEAP, R.B.; WOODING,
F.B.P. Regulation of steroid synthesis and metabolism in isolated binucleate cells of the placenta in sheep and goats. J. Reprod. Fertil., v.94, p.203-11, 1992.

WILLIAMS, W.F.; MARGOLIS, M.J.; MANSPEAKER, J. et al. Peripartum changes in the bovine placenta related to fetal membrane retention. Theriogenology, v.28, p.213-223, 1987.

WOODING, F.B.P. Current topic: The synepitheliochorial placenta of ruminants: binucleate cell fusions and hormone production. Placenta, v.13, p.101-113, 1992.

WOODING, F.B.P. Frequency and localisation of binucleate cells in the placentomes of ruminants. Placenta, v.4, p.527-540, 1983.

WYLLIE, A.H. Glucocorticoid induced thymocytes apoptosis in associated with endogenous endonuclease activation. Nature, v.284, p.555-556, 1980. 